\title{
Phosphate Recovery from Human Waste via the Formation of Hydroxyapatite during Electrochemical Wastewater Treatment
}

\author{
Clément A. Cid, ${ }^{\dagger}$ Justin T. Jasper, ${ }^{\dagger}{ }^{\circ}$ and Michael R. Hoffmann* \\ Linde-Robinson Laboratories, California Institute of Technology, 1200 E California Blvd, Pasadena, California 91125, United States
}

Supporting Information

ABSTRACT: Electrolysis of toilet wastewater with $\mathrm{TiO}_{2}$-coated semiconductor anodes and stainless steel cathodes is a potentially viable onsite sanitation solution in parts of the world without infrastructure for centralized wastewater treatment. In addition to treating toilet wastewater, pilot-scale and bench-scale experiments demonstrated that electrolysis can remove phosphate by cathodic precipitation as hydroxyapatite at no additional energy cost. Phosphate removal could be predicted based on initial phosphate and calcium concentrations, and up to $80 \%$ total phosphate removal was achieved. While calcium was critical for phosphate removal, magnesium and bicarbonate had only minor impacts on phosphate removal rates at concentrations typical of toilet wastewater.

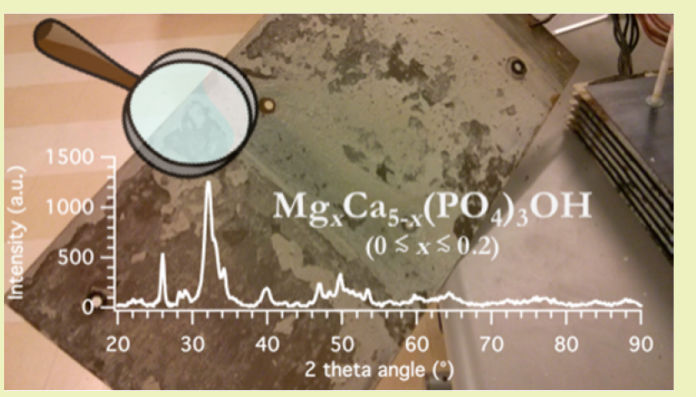
Optimal conditions for phosphate removal were 3 to 4 h treatment at about $5 \mathrm{~mA} \mathrm{~cm}{ }^{-2}(\sim 3.4 \mathrm{~V})$, with greater than $20 \mathrm{~m}^{2} \mathrm{~m}^{-3}$ electrode surface area to reactor volume ratios. Pilot-scale systems are currently operated under similar conditions, suggesting that phosphate removal can be viewed as an ancillary benefit of electrochemical wastewater treatment, adding utility to the process without requiring additional energy inputs. Further value may be provided by designing reactors to recover precipitated hydroxyapatite for use as a low solubility phosphorus-rich fertilizer.

KEYWORDS: Electrochemical precipitation, Phosphorus, Phosphate removal, Wastewater, Onsite sanitation

\section{INTRODUCTION}

Discharge of phosphorus-containing wastewater to surface waters can cause algal blooms, leading to growth of toxic cyanobacteria, hypoxia, and disruption of food webs. ${ }^{1,2}$ At the same time, phosphorus is a limited resource with an average price that has nearly tripled between 2005 and $2015,{ }^{3}$ making the recovery of phosphorus from waste crucial. ${ }^{4}$ Toilet and domestic wastewater are an important source of phosphorus, as up to $22 \%$ of the world's consumption of phosphorus could be recovered from human urine and feces. ${ }^{5,6}$ Recovery of phosphorus from toilet wastewater or septic systems could therefore reduce phosphorus pollution as well as reduce dependency on imported mineral phosphate in countries where access to affordable fertilizers is limited. ${ }^{7}$

Enhanced biological phosphorus removal (EBPR) may provide effective phosphorus recovery in centralized wastewater treatment processes, ${ }^{8}$ but in rural communities, small onsite sanitation systems (e.g., septic tanks, latrines, or cesspools) make this technology challenging without engineered processes to maintain the correct microbial population. ${ }^{9}$ Phosphorus recovery in rural communities can be accomplished via forced precipitation as struvite $\left(\mathrm{NH}_{4} \mathrm{MgPO}_{4} \cdot 6 \mathrm{H}_{2} \mathrm{O}\right)$ or hydroxyapatite $\left(\mathrm{Ca}_{5}\left(\mathrm{PO}_{4}\right)_{3} \mathrm{OH}\right)$, but these strategies typically require separation of urine and feces, addition of chemicals, or use of sacrificial electrodes that further complicates and increases the cost of existing wastewater treatment strategies. ${ }^{10-12}$

Electrochemical systems have previously been suggested for phosphorus removal from wastewater. Electrochemical coagu- lation of phosphate from synthetic wastewater has been achieved using sacrificial aluminum or iron anodes, ${ }^{13,14}$ as well as magnesium anodes, which allowed for struvite recovery from ammonium-containing solutions. ${ }^{15}$ However, this type of electrode is depleted by oxidation and needs to be replaced on a regular basis. Alternatively, an alkaline catholyte chamber separated from the anode by a cation exchange membrane has been incorporated into an electrochemical system to homogeneously precipitate phosphate as hydroxyapatite from synthetic wastewater. ${ }^{16}$ Electrochemical deposition of struvite directly onto a nickel cathode has been demonstrated in synthetic solutions containing magnesium, ammonium, and phosphate, due to the increased $\mathrm{pH}$ near the cathode surface. ${ }^{17}$ However, these systems provided phosphorus removal alone, and none of these studies investigated authentic toilet wastewater or utilized a system that was practical for toilet wastewater treatment.

Onsite electrochemical wastewater treatment is an appealing technology for small- and medium-sized treatment and recycling systems, providing treatment without requiring construction of traditional wastewater infrastructure. ${ }^{18}$ One promising electrochemical treatment system under development by Hoffmann et al. ${ }^{19}$ couples stainless steel cathodes to stable layered-layered semiconductor anodes

Received: September 7, 2017

Revised: February 1, 2018

Published: February 5, 2018 
$\left(\left[\mathrm{Bi}_{2} \mathrm{O}_{3}\right]_{z}\left[\mathrm{TiO}_{2}\right]_{1-z} / \mathrm{Ir}_{x} \mathrm{Ta}_{y} \mathrm{O}_{2} / \mathrm{Ti}\right)^{20-22}$ treating the toilet wastewater in a sequential batch reactor at constant potential $(3.5 \pm 0.25 \mathrm{~V})$ with a typical residence time of 3-4 h. Benchscale experiments and long-term field-testing have shown effective wastewater disinfection due to generation of hypochlorous acid from the oxidation of chloride, as well as reduction of chemical oxygen demand, transformation of trace organic chemicals, and removal of ammonium via breakpoint chlorination. ${ }^{20,22-25}$

The purpose of this study was to evaluate the potential for phosphate removal from human wastewater during electrochemical treatment using the same combined anode-cathode system previously shown to provide efficient wastewater treatment. ${ }^{20,23,24}$ Phosphate-containing precipitates were identified and phosphate removal efficiencies were measured in authentic and synthetic toilet wastewater. Experiments in synthetic wastewater allowed quantification of the effects of ion composition, buffering capacity, current density, and electrode surface area to volume ratio on phosphate removal kinetics and equilibria.

\section{MATERIALS AND METHODS}

Materials. All reagents were of analytical grade or higher purity. Solutions were prepared using $\geq 18 \mathrm{M} \Omega \mathrm{cm}$ Milli- $Q$ water from a Millipore system.

Toilet (human) wastewater containing an uncontrolled mixture of urine, feces, and flushing water was taken from a previously described public recycling wastewater treatment system located on the California Institute of Technology campus (Pasadena, CA) via a macerator pump. ${ }^{25}$ The residence time in the wastewater tank was approximately $160 \mathrm{~d}$. Synthetic wastewater was formulated to replicate the ionic composition and $\mathrm{pH}(8.3)$ of the toilet wastewater (Table 1) by

Table 1. Composition of Toilet Wastewater in Onsite Wastewater Treatment System and Buffering Capacity of Relevant Species

\begin{tabular}{lll}
\multicolumn{1}{c}{ component } & \multicolumn{1}{c}{ value } & \multicolumn{1}{c}{ buffer capacity $\left(\beta_{\mathrm{i}}\right)^{b}$} \\
$\mathrm{Ca}^{2+}$ & $1.0 \mathrm{mM}$ & 0 \\
$\mathrm{Cl}^{-}$ & $24 \mathrm{mM}$ & 0 \\
$\mathrm{HCO}_{3}{ }^{-}+\mathrm{CO}_{3}{ }^{2-}$ & $17 \mathrm{mM}$ & 0.79 mequiv L ${ }^{-1} \mathrm{pH}^{-1}$ \\
$\mathrm{~K}^{+}$ & $6.1 \mathrm{mM}$ & 0 \\
$\mathrm{Mg}^{2+}$ & $0.8 \mathrm{mM}$ & 0 \\
$\mathrm{Na}^{+}$ & $27 \mathrm{mM}$ & 0 \\
$\mathrm{NH}_{4}{ }^{+}$ & $13 \mathrm{mM}$ & 2.71 mequiv L ${ }^{-1} \mathrm{pH}^{-1}$ \\
$\mathrm{PO}_{4}{ }^{3-}{ }^{-}$ & $0.6 \mathrm{mM}$ & 0.09 mequiv L $\mathrm{L}^{-1} \mathrm{pH}^{-1}$ \\
$\mathrm{SO}_{4}{ }^{2-}$ & $3.0 \mathrm{mM}$ & 0 \\
$\mathrm{COD}^{d}$ & $320-380 \mathrm{mg} \mathrm{O} / \mathrm{L}$ & \\
$\mathrm{pH}$ & 8.3 &
\end{tabular}

${ }^{a}$ Collected after $180 \mathrm{~d}$ of operation. ${ }^{b}$ At $\mathrm{pH}$ 8.3. ${ }^{c}$ Total phosphate. ${ }^{d}$ Chemical oxygen demand.

dissolving the following salts in water: $\mathrm{NaCl}(17.1 \mathrm{mM}), \mathrm{NaHCO}_{3}$ (4.7 mM), $\mathrm{NaH}_{2} \mathrm{PO}_{4} \cdot \mathrm{H}_{2} \mathrm{O}(0.6 \mathrm{mM}), \mathrm{Na}_{2} \mathrm{SO}_{4}(2.1 \mathrm{mM}), \mathrm{MgCl}_{2}$. $6 \mathrm{H}_{2} \mathrm{O}(0.8 \mathrm{mM}), \mathrm{CaCl}_{2} \cdot 2 \mathrm{H}_{2} \mathrm{O}(1 \mathrm{mM}), \mathrm{KCl}(3.6 \mathrm{mM}),\left(\mathrm{NH}_{4}\right)_{2} \mathrm{SO}_{4}$ $(0.9 \mathrm{mM}), \mathrm{NH}_{4} \mathrm{HCO}_{3}(12.1 \mathrm{mM})$, and $\mathrm{KOH}(2.5 \mathrm{mM})$. Ion concentrations were adjusted to test the effect of individual ions on phosphate removal rates.

Electrode arrays consisted of mixed metal oxide anodes $\left(\mathrm{Bi}_{2} \mathrm{O}_{3}\right]_{z}\left[\mathrm{TiO}_{2}\right]_{1-z} / \mathrm{Ir}_{x} \mathrm{Ta}_{y} \mathrm{O}_{2} / \mathrm{Ti}$ ) and stainless steel cathodes (Nanopac, Korea) and were similar to those developed by Weres ${ }^{26,27}$ and used in previous electrochemical wastewater treatment studies. . $^{2,23-25,28}$

Pilot-Scale Experiments. Pilot-scale experiments were performed in batch mode in a $40-\mathrm{L}$ acrylic reactor ( $22 \mathrm{~L}$ working volume) mixed with a circulation pump $\left(10 \mathrm{~L} \mathrm{~min}^{-1}\right)$, as described previously. ${ }^{24,29}$ Electrode arrays ( 7 anodes and 8 cathodes) were sandwiched with a 3 $\mathrm{mm}$ separation. The active geometric anodic surface area was $1.8 \mathrm{~m}^{2}$, giving a surface area to effective volume ratio of $80 \mathrm{~m}^{2} \mathrm{~m}^{-3}$. Pilot-scale experiments were conducted using a potentiostatic power supply coupled with a data logger (Program Scientific Instruments, U.S.A.) with a potential set between 3.3 and $3.5 \mathrm{~V}$. Ion recoveries as precipitate were calculated in selected experiments by calculating ion masses in the formed precipitate (Figure S1) using the average precipitate composition and comparing those masses to ion removal from the aqueous phase.

Bench-Scale Experiments. Bench-scale experiments were conducted to study the role of ionic composition, buffering capacity, and current density on phosphate removal kinetics and equilibria using anode and cathode pieces cut from a pilot-scale array. The electrode spacing $(3 \mathrm{~mm})$ and electrode surface area to volume ratio $\left(\sim 35 \mathrm{~m}^{2}\right.$ $\mathrm{m}^{-3}$ ) were comparable to the pilot-scale system. The electrode array was either operated potentiostatically (typically $3.5 \mathrm{~V}$ between anode and cathode) or galvanostatically $\left(\sim 10 \mathrm{~mA} \mathrm{~cm}{ }^{-2} ; 3.75 \mathrm{~mA} \mathrm{~mL}{ }^{-1}\right)$ using a battery cycler (Neware, China). Experiments were conducted in open beakers with magnetic stirring $(600 \mathrm{rpm})$.

The role of wastewater composition was studied by varying calcium, magnesium, phosphate, and bicarbonate concentrations over the range of values expected in toilet wastewater (i.e., typical values present in human waste diluted approximately 10 times by flushing; Table S1 and Figure S2). The role of buffering capacity was studied by adding borate $(0-100 \mathrm{mM})$ to synthetic wastewater at $\mathrm{pH} 8.3$. No ion interactions with borate were predicted by Visual MINTEQ 3.1 software. ${ }^{30}$ The effects of wastewater volume to electrode surface area ratios $(\sim 10-35$ $\mathrm{m}^{2} \mathrm{~m}^{-3}$ ) were studied by adjusting the solution volume while using the same size electrodes. The effects of current density were investigated by increasing the current density galvanostatically $\left(\sim 3-55 \mathrm{~mA} \mathrm{~cm}^{-2}\right.$; $\left.1-20 \mathrm{~mA} \mathrm{~mL} \mathrm{~m}^{-1}\right)$. Energy efficiency of phosphate removal was calculated based on the final phosphate concentration and the total amount of electrical energy consumed.

Precipitate Solubility Measurements. Precipitate scraped from the stainless-steel cathodes or collected from the pilot-scale reactor bottom was rinsed with deionized water and dried at $70{ }^{\circ} \mathrm{C}$ overnight before being ground for analysis. The solubility product constant $\left(K_{\mathrm{sp}}\right)$ of the collected precipitate was measured in dilute phosphoric acid solutions $(\sim 0.1 \mathrm{mM})$ adjusted to $\mathrm{pH} 6$ with sodium hydroxide, as described previously. ${ }^{31}$ Precipitate $(0.1 \mathrm{~g})$ was added to vials $(25 \mathrm{~mL})$ capped with minimal headspace. Vials were mixed on a rotisserie for 8 $\mathrm{d}$ at $22{ }^{\circ} \mathrm{C}$ and solid precipitate remained at the end of the experiment. The $K_{\mathrm{sp}}$ for hydroxyapatite was calculated according to

$$
K_{\mathrm{sp}}=\left(\mathrm{Ca}^{2+}\right)^{5}\left(\mathrm{PO}_{4}^{3-}\right)^{3}\left(\mathrm{OH}^{-}\right)
$$

Solubility indices (SI), as defined by eq 2 , and ion activity products (IAP) were calculated using Visual MINTEQ 3.1 software, $^{30}$ accounting for ion pairs (e.g., $\mathrm{CaPO}_{4}{ }^{-}$). Equilibrium calculations and supersaturated conditions for various minerals were determined using the same software, taking into consideration ion concentrations listed in Table 1.

$$
\mathrm{SI}=\log \mathrm{IAP}-\log K_{\mathrm{sp}}
$$

Analytical Methods. X-ray powder diffraction spectra (Philips PANalytical X'Pert Pro X-ray) were collected for crystal phase analysis. Thermogravimetric analysis was conducted for moisture content determination and qualitative mineral identification (PerkinElmer STA 6000). Scanning electron microscope imaging and energy dispersive spectrometry (SEM/EDS; Zeiss 1550VP Field Emission with Oxford $\mathrm{X}$-Max SDD X-ray) were used for surface topography and elemental analysis. A "site" represented an indistinguishable agglomerate of amorphous or crystallized material.

The chloride, sulfate, nitrate, phosphate, ammonium, potassium, calcium, and magnesium contents of collected precipitates were determined by dissolution in $1 \mathrm{M}$ sulfuric acid or $1 \mathrm{M}$ nitric acid and analysis by ion chromatography (Dionex ICS 2000; AS19G anions, CS12A cations). ${ }^{32}$ Precipitate carbonate content was determined by 
manometric carbon dioxide measurement following dissolution in acid $(6 \mathrm{M} \mathrm{HCl}){ }^{33}$

Samples for aqueous ion concentrations were diluted $(10-25 \times)$ and measured by ion chromatography as described above.

\section{RESULTS AND DISCUSSION}

Phosphate Removal during Pilot-Scale Treatment. Electrolysis of collected toilet wastewater in the pilot-scale onsite treatment system resulted in removal of total phosphate, magnesium, and calcium over the $5 \mathrm{~h}$ treatment cycle (Figure 1;

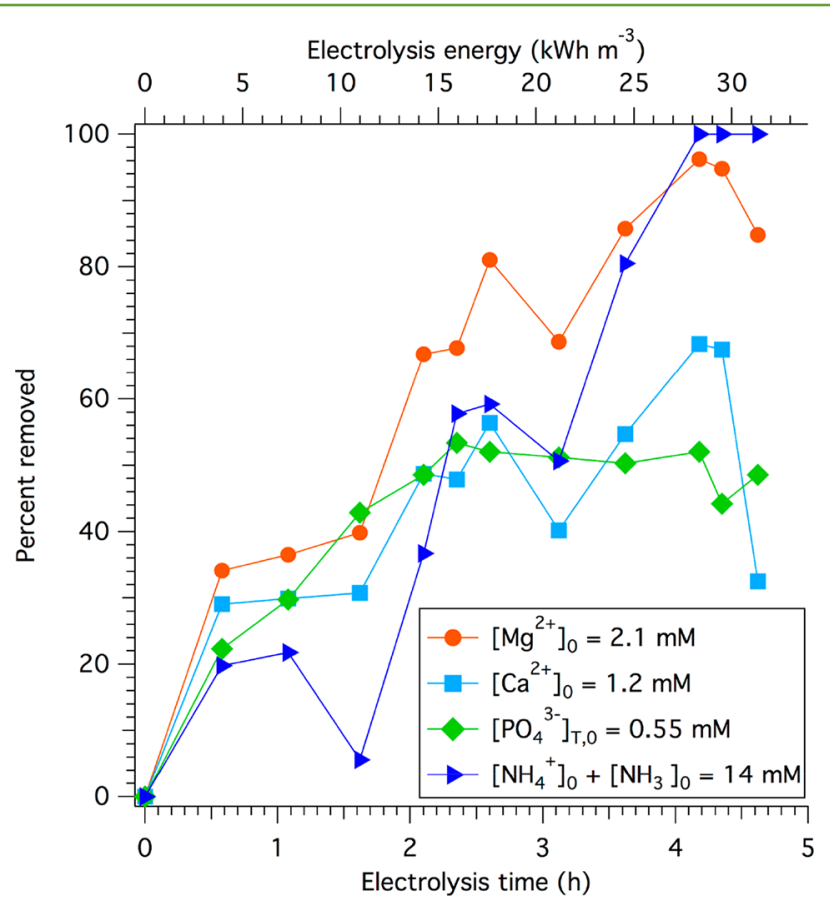

Figure 1. $\mathrm{Mg}^{2+}, \mathrm{Ca}^{2+}, \mathrm{PO}_{4}{ }^{3-}$ T, and ammonia $\left(\mathrm{NH}_{4}{ }^{+}+\mathrm{NH}_{3}\right)$ percent removal during electrochemical treatment $(3.3 \mathrm{~V} ; 50 \mathrm{~A})$ of toilet wastewater $\left(\left[\mathrm{Cl}^{-}\right]=80 \mathrm{mM}\right)$ in pilot-scale reactor. Initial ion concentrations are indicated in the legend.

$50 \%$ total $\mathrm{PO}_{4}{ }^{3-}\left(\mathrm{PO}_{4}{ }^{3-} \mathrm{T}\right), 89 \% \mathrm{Mg}^{2+}, 42 \% \mathrm{Ca}^{2+}$ removed). Total phosphate removal was similar to predictions based on initial calcium and phosphate concentrations (see below). Breakpoint chlorination was achieved in approximately $4 \mathrm{~h}$ with complete ammonia removal ${ }^{34}$ and subsequent production of free chlorine (Figure S3). Concurrent with electrolysis, a greyish precipitate flaked off the stainless-steel cathodes into solution (Figure S1). Precipitate recovered from the cathodes and the bottom of the reactor after treatment accounted for more than $90 \%$ of the calcium and total phosphate removed based on the measured precipitate composition. Pilot-scale phosphorus removal was therefore primarily attributed to electrochemically induced precipitation.

Characterization of Precipitated Hydroxyapatite. Precipitate collected from the pilot-scale electrochemical reactor was primarily composed of hydroxyapatite $\left(\mathrm{Ca}_{5}(\mathrm{PO} 4)_{3} \mathrm{OH}\right)$, based on X-ray diffraction spectroscopy (Figure 2). The crystallinity of the precipitate was found to be significantly higher than hydroxyapatite formed by homogeneous precipitation in synthetic dairy manure wastewater, ${ }^{35}$ as evidenced by resolution of peaks at $2 \theta$ values of $28^{\circ}$, $29^{\circ}, 31^{\circ}$, and $32^{\circ}$.

In addition to phosphate ( $30 \pm 2 \%$ by mass) and calcium ( 18 $\pm 1 \%$ by mass), the precipitate was composed of chemically

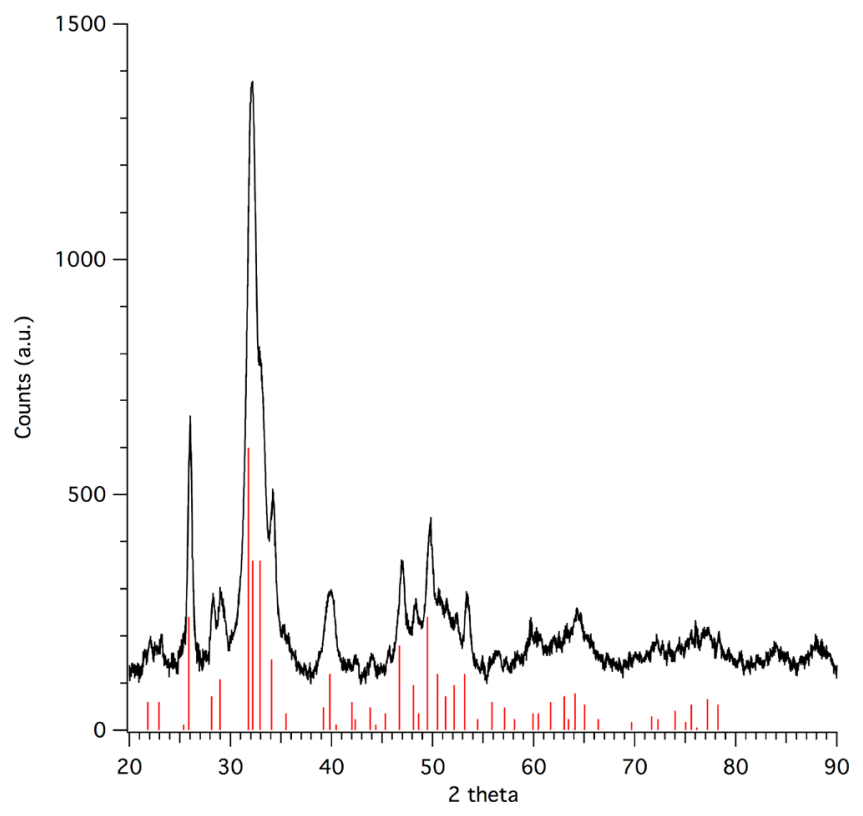

Figure 2. X-ray diffraction spectrum of collected precipitate. Overlay of pure hydroxyapatite with highest peak normalized to $600 \mathrm{au}$ (ICSD no. 24240 and PDF no. 01-073-1731) is in red sticks.

bound water (8-20\% by thermogravimetry; Figure S4), magnesium $(6 \pm 1 \%)$, carbonate $(6 \pm 1 \%)$, silicate $(9 \pm$ $3 \%)$, and undissolvable material (3-6\%; Table 2). Magnesium

Table 2. Collected Precipitate Composition

\begin{tabular}{lll}
\multicolumn{1}{r}{ component } & \multicolumn{1}{c}{$\%$ mass } & \multicolumn{1}{c}{ detection method } \\
$\mathrm{Ca}^{2+}$ & $18-19 \%$ & IC; SEM-EDS \\
$\mathrm{Mg}^{2+}$ & $5-7 \%$ & IC; SEM-EDS \\
$\mathrm{PO}_{4}{ }^{3-}{ }_{\mathrm{T}}$ & $27-32 \%$ & IC; SEM-EDS \\
$\mathrm{CO}_{3}{ }^{2-}$ & $6 \pm 1 \%$ & acid digestion \\
$\mathrm{SiO}_{4}{ }^{2-a}$ & $9 \pm 3 \%$ & SEM-EDS, assuming $\mathrm{Si} \mathrm{is} \mathrm{SiO}_{4}$ \\
$\mathrm{H}_{2} \mathrm{O}$ & $8-20 \%$ & vacuum oven; TGA \\
$\begin{array}{l}\text { organics; undigested } \\
\text { material }\end{array}$ & $3-6 \%$ & filter acid-dissolved precipitate \\
total & & solution
\end{tabular}

${ }^{a} \mathrm{SiO}_{4}{ }^{2-}$ was only detected in samples collected from a silicon-grease sealed electrochemical reactor.

and carbonate are commonly observed to substitute for calcium and hydroxide, respectively, in hydroxyapatite ${ }^{35-38}$ and may affect precipitation kinetics. Silicate is known to substitute for phosphate in hydroxyapatite $\left(\mathrm{Ca}_{10}\left(\mathrm{PO}_{4}\right)_{6-x}\left(\mathrm{SiO}_{4}\right)_{x}(\mathrm{OH})_{2-x}\right)^{39}$ and was only observed in reactors sealed with silicon grease. Chloride, sulfate, nitrate, ammonium, potassium, and sodium were not present in collected precipitates in significant amounts (less than $1 \%$ by mass), as expected for hydroxyapatite.

SEM/EDS mapping of collected precipitate revealed a homogeneous distribution of elements with phosphorus, calcium, and magnesium in all deposits (Figure S5). Scanning of several particles showed ratios of $\mathrm{Ca} / \mathrm{P}=1.5 \pm 0.3, \mathrm{Mg} / \mathrm{P}=$ $1.0 \pm 0.2$, and $\mathrm{O} / \mathrm{P}=5.0 \pm 1.6$. The low $\mathrm{Ca} / \mathrm{P}$ ratios observed as compared to pure hydroxyapatite $(\mathrm{Ca} / \mathrm{P}=1.67)$ could be explained by substitution of magnesium for calcium and silicate for phosphate $((\mathrm{Ca}+\mathrm{Mg}) /(\mathrm{Si}+\mathrm{P})=1.7 \pm 0.2)$.

The measured $K_{\mathrm{sp}}$ of the electrochemically deposited hydroxyapatite $\left(5.0 \pm 0.5 \times 10^{-47}\right)$ was significantly larger than literature values for pure hydroxyapatite $(3.04 \pm 0.25 \times$ 
$\left.10^{-59}\right),,^{31}$ likely due to incorporation of magnesium, carbonate, and silicate. ${ }^{40}$ For example, incorporation of a similar mass percentage of carbonate (i.e., $\sim 4 \%$ by mass) into hydroxyapatite can increase hydroxyapatite's $K_{\mathrm{sp}}$ by more than 8 orders of magnitude. ${ }^{37}$ Electrochemically deposited hydroxyapatite solubility may also have been lower than that of pure hydroxyapatite, since it was not completely crystalline (Figure 2).

Although no precipitation was observed before electrolysis, ${ }^{41}$ the collected toilet wastewater (Table 1) was supersaturated with respect to aragonite and calcite $(\mathrm{SI} \approx 0.9$ and 1.1 ), disordered and ordered dolomite $(\mathrm{SI} \approx 1.7$ and 2.2$),{ }^{42} \alpha$ and $\beta$ tricalcium phosphate $(S I \approx 2.2$ and 2.9 ), and tetracalcium phosphate $(\mathrm{SI} \approx 2.3)$. Toilet wastewater was also supersaturated with respect to pure hydroxyapatite $(\mathrm{SI} \approx 12)$, which was the thermodynamically favored mineral phase. However, toilet wastewater was slightly below saturation with respect to the measured solubility of the electrochemically formed precipitate $(\mathrm{SI}=-0.2)$.

Phosphate Removal Equilibria and Kinetics. Phosphate Removal in Synthetic versus Authentic Wastewater. Synthetic wastewater was used to determine the effect of wastewater composition ( $\left[\mathrm{Ca}^{2+}\right],\left[\mathrm{Mg}^{2+}\right],\left[\mathrm{HCO}_{3}^{-}\right]$, and $\left.\left[\mathrm{PO}_{4}{ }^{3-}\right]_{\mathrm{T}}\right)$, buffering capacity, and current density on phosphate removal (Figure S6). Despite the lack of organic matter in synthetic wastewaters, which may reduce hydroxyapatite formation rates, ${ }^{43}$ calcium, magnesium, and total phosphate removal was found to be comparable to that observed with authentic toilet wastewater (Figure 3). The XRD spectrum of a stainless steel cathode after consecutive synthetic wastewater electrolysis cycles also exhibited similar peaks as the precipitate formed in the pilot-scale reactor (Figures S7 and 2).
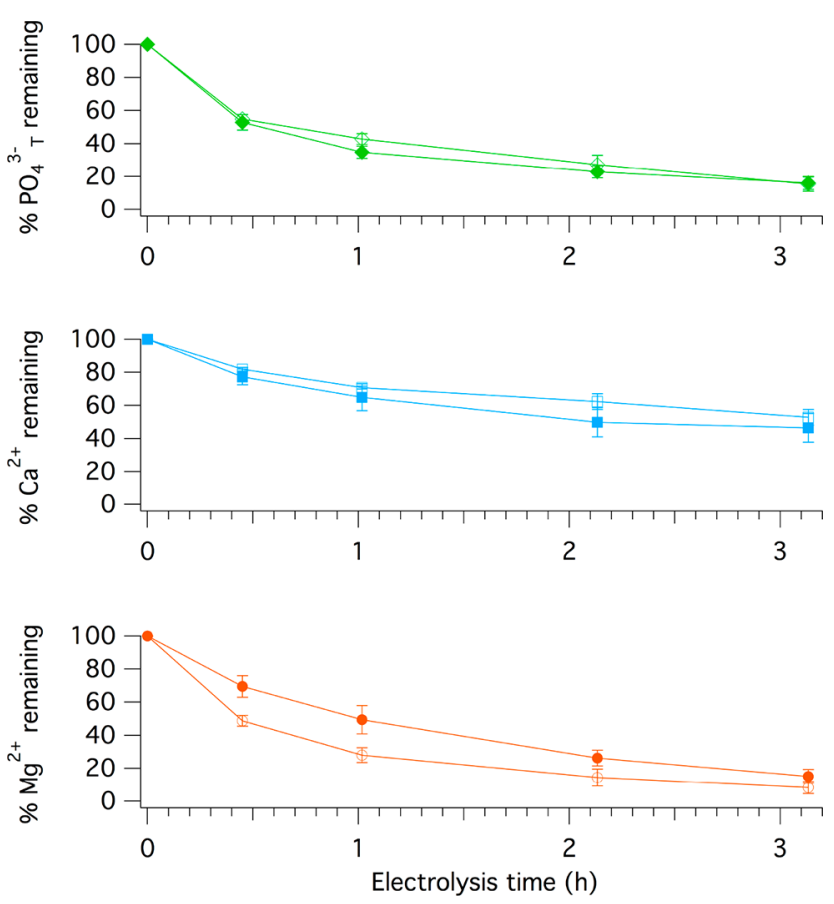

Figure 3. Percent $\mathrm{PO}_{4}{ }^{3-} \mathrm{T}, \mathrm{Ca}^{2+}$, and $\mathrm{Mg}^{2+}$ remaining during potentiostatic electrochemical treatment $\left(3.6 \mathrm{~V} ; \sim 18 \mathrm{~mA} \mathrm{~cm}{ }^{-2}\right)$ of genuine toilet wastewater (filled markers) and synthetic wastewater (empty markers) with similar ionic compositions. $\left[\mathrm{PO}_{4}{ }^{3-}\right]_{\mathrm{T}, 0} \approx 0.5$ $\mathrm{mM} ;\left[\mathrm{Ca}^{2+}\right]_{0} \approx 1.3 \mathrm{mM} ;\left[\mathrm{Mg}^{2+}\right]_{0} \approx 1.3 \mathrm{mM}$. Error bars represent \pm one standard deviation of three replicates.
The majority of the phosphate removed was recovered as a precipitate on the cathode $(70-100 \%)$, indicating that phosphate removal was primarily due to hydroxyapatite formation. Synthetic wastewater was therefore taken to be a good proxy for genuine toilet wastewater for these experiments.

Extent of Phosphate Removal. In synthetic wastewater, percent phosphate removal at equilibrium $(\sim 3-4 \mathrm{~h})$ could typically be predicted (Figure 4 ) based on initial calcium and

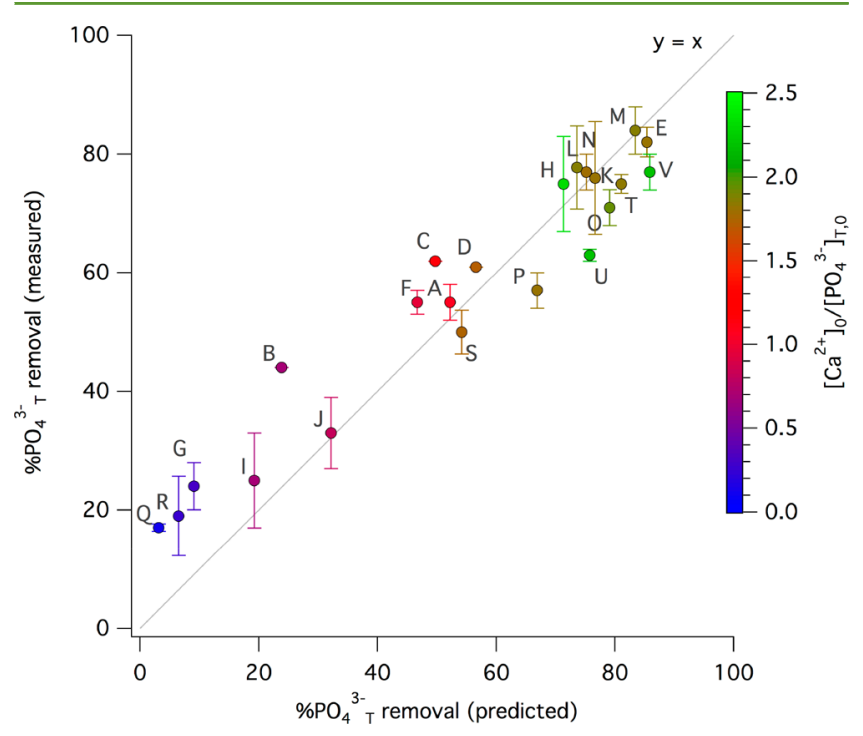

Figure 4. Measured vs predicted percent total phosphate removal following galvanostatic electrolysis $\left.(4 \mathrm{~h} ; 10 \mathrm{~mA} \mathrm{~cm})^{-2}\right)$. Error bars represent \pm standard deviation of three replicates. Experiments are referenced by letter and are described in Table S1.

phosphate concentrations by solving the simultaneous equations for the hydroxyapatite solubility product (eq 1) and the mass balance for calcium and phosphate removal (eq 3) at a cathodic $\mathrm{pH}$ of about 9.4 (Table S1). The cathodic $\mathrm{pH}$ was estimated assuming that the solution at the cathode surface was equilibrated (SI $=1)$ with respect to electrochemically precipitated hydroxyapatite $\left(K_{\mathrm{sp}}=5 \times 10^{-47}\right)$ and that $\left[\mathrm{Ca}^{2+}\right]$ and $\left[\mathrm{PO}_{4}{ }^{3-}\right]$ at the cathode were the same as measured in solution at the end of the experiment (when ion concentrations had stabilized).

$$
\frac{5}{3}\left(\left[\mathrm{PO}_{4}^{3-}\right]_{\mathrm{T}, 0}-\left[\mathrm{PO}_{4}^{3-}\right]_{\mathrm{T}, \mathrm{fin}}\right)=\left(\left[\mathrm{Ca}^{2+}\right]_{0}-\left[\mathrm{Ca}^{2+}\right]_{\mathrm{fin}}\right)
$$

However, for low ratios of calcium to total phosphate, phosphate removal was greater than predicted. This may have been due to precipitation of calcium-phosphate minerals poor in calcium, such as amorphous calcium phosphate $\left(\mathrm{Ca}_{3}\left(\mathrm{PO}_{4}\right)_{2}\right.$. $\left.n \mathrm{H}_{2} \mathrm{O} ; K_{\mathrm{sp}}=2.49 \times 10^{-7}\right)$, dicalcium phosphate dihydrate $\left(\mathrm{CaHPO}_{4} \cdot 2 \mathrm{H}_{2} \mathrm{O} ; K_{\mathrm{sp}}=1.26 \times 10^{-7}\right)$, and others. ${ }^{43}$ Other deviations between predicted and observed percent phosphate removal could be explained by the presence of magnesium or variations in the applied current density (see below).

Based on eqs 1 and 3, high phosphate removal is predicted at high initial calcium concentrations and high initial ratios of calcium to phosphate concentrations (Figure 5). Reliance on high calcium concentrations for efficient phosphate removal is a limitation of this technology. However, urine in toilet wastewater typically contains sufficient calcium to achieve 


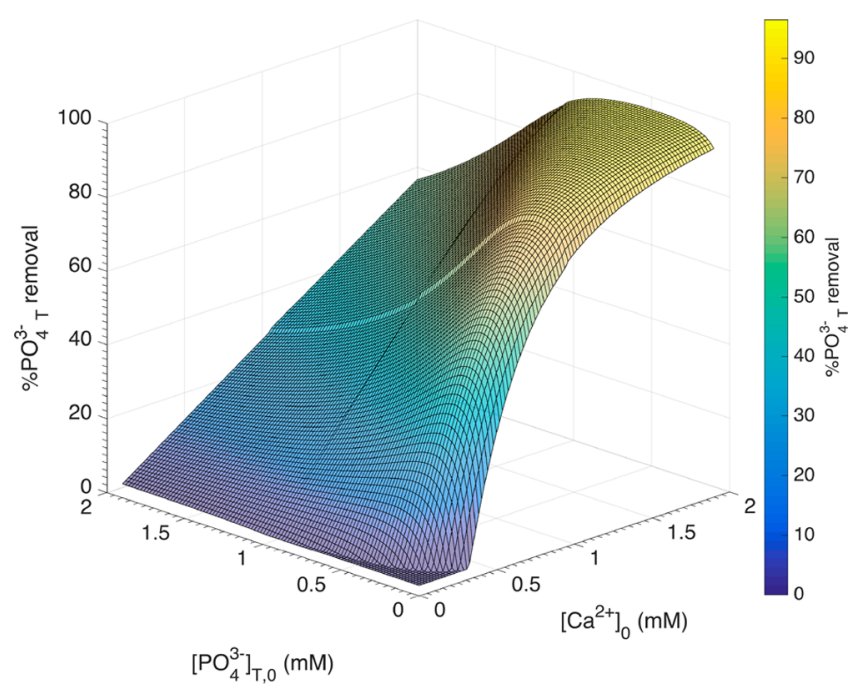

Figure 5. Predicted percent total phosphate removal. Predictions are based on solving the simultaneous eqs 1 and 3 at varying initial total phosphate and calcium concentrations and a cathodic $\mathrm{pH}$ of 9.4.

greater than $50 \%$ phosphate removal (i.e., $\sim 1 \mathrm{mM}$ following $\sim 10 \times$ dilution by flushing). ${ }^{44}$

Electrochemical Phosphate Precipitation Rates. In synthetic wastewater initial electrochemical phosphate precipitation rates $\left(k_{\text {ini }}\right)$ were determined based on calcium and phosphate concentrations during the first $3 \mathrm{~h}$ of treatment (Figure S6). Initial phosphate precipitation rates increased from about 0.05 to $0.25 \mathrm{mM} \mathrm{h}^{-1}$ with the product $\left[\mathrm{Ca}^{2+}\right]\left[\mathrm{PO}_{4}{ }^{3-}\right]$ (Figure 6), as expected based on a homogeneous hydroxyapatite precipitation model (eq 4) previously developed by Inskeep and Silvertooth. ${ }^{45}$ In their study, Inskeep and Silvertooth found that the precipitation rate of hydroxyapatite

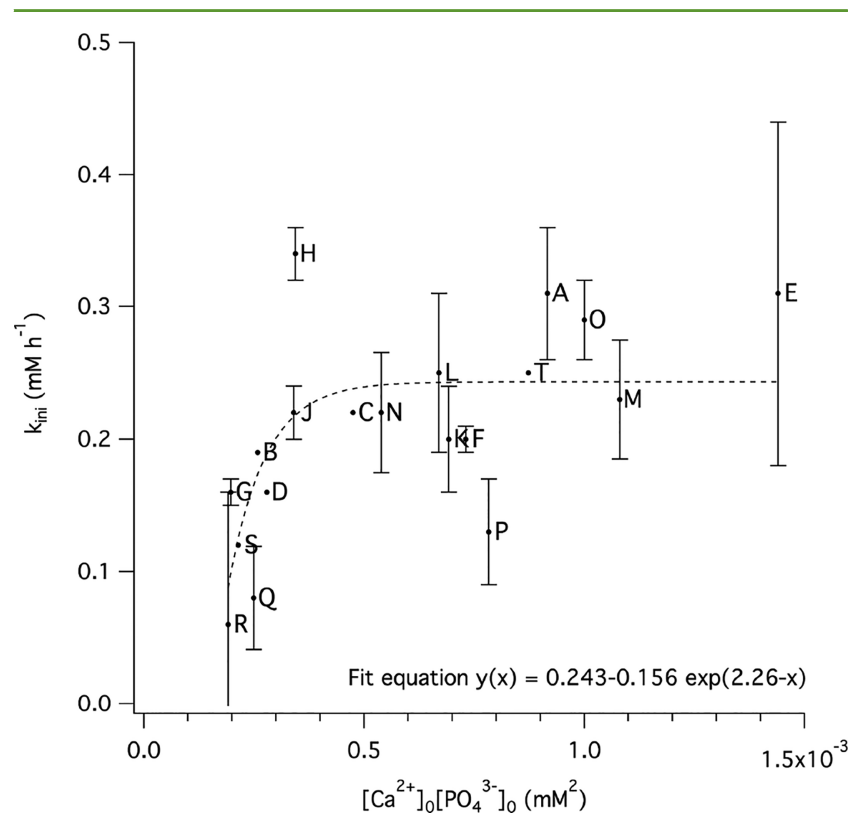

Figure 6. Initial rate constants $\left(k_{\text {ini }}\right)$ for the formation of hydroxyapatite during galvanostatic electrolysis $\left(10 \mathrm{~mA} \mathrm{~cm}^{-2}\right)$ as a function of $\left[\mathrm{Ca}^{2+}\right]_{0}\left[\mathrm{PO}_{4}{ }^{3-}\right]_{0}$. The fit equation was determined empirically using Igor Pro 6.37 (Wavemetrics). Error bars represent \pm standard deviation of three replicates. Experiments are referenced by letter and are described in Table S1. had a first-order dependence on calcium and phosphate and did not directly depend on $\left[\mathrm{OH}^{-}\right]$(the influence of $\mathrm{pH}$ was accounted for by $\mathrm{PO}_{4}{ }^{3-}$ ).

$$
\frac{\mathrm{d}[\mathrm{HAP}]}{\mathrm{d} t}=k_{\mathrm{f}}\left[\mathrm{Ca}^{2+}\right]\left[\mathrm{PO}_{4}^{3-}\right] \approx k_{\mathrm{ini}}
$$

Above $\left[\mathrm{Ca}^{2+}\right]\left[\mathrm{PO}_{4}{ }^{3-}\right]$ values of $0.4 \mathrm{mM}^{2}$, however, initial phosphate removal rates were constant at about $0.25 \mathrm{mM} \mathrm{h}^{-1}$, suggesting that initial precipitation was mass limited only at low calcium and phosphate concentrations. In all cases, though, removal rates were sufficient to reach equilibrium within 3 to 4 $\mathrm{h}$, which is a typical treatment cycle for disinfection and ammonium removal during onsite electrochemical wastewater treatment in the system developed by Hoffmann et al. ${ }^{21,28}$

Effect of Magnesium on Phosphate Removal. Adsorption of magnesium onto actively growing crystals during homogeneous hydroxyapatite precipitation and subsequent substitution of magnesium for calcium has been shown to reduce hydroxyapatite growth rates and increase hydroxyapatite solubility. ${ }^{36,46,47}$ However, effects were generally significant only at concentrations above $1 \mathrm{mM},{ }^{48}$ which is the maximum magnesium concentration expected in toilet wastewater assuming about 10 times dilution by flushing water. ${ }^{44}$

As expected, electrochemical treatment of synthetic wastewater with $1 \mathrm{mM}$ calcium, $0.6 \mathrm{mM}$ phosphate, and varying magnesium concentrations up to $1 \mathrm{mM}$ showed no significant change in initial phosphate removal rates (Figure 7a) or percent phosphate removal (Figure 8a). In fact, at calcium concentrations below $1 \mathrm{mM}$ with $0.5 \mathrm{mM}$ total phosphate, phosphate removal percentages were higher than predicted based on calcium concentrations alone in the presence of $1 \mathrm{mM}$ magnesium (Figure 8b, compare experiments B, C, and D
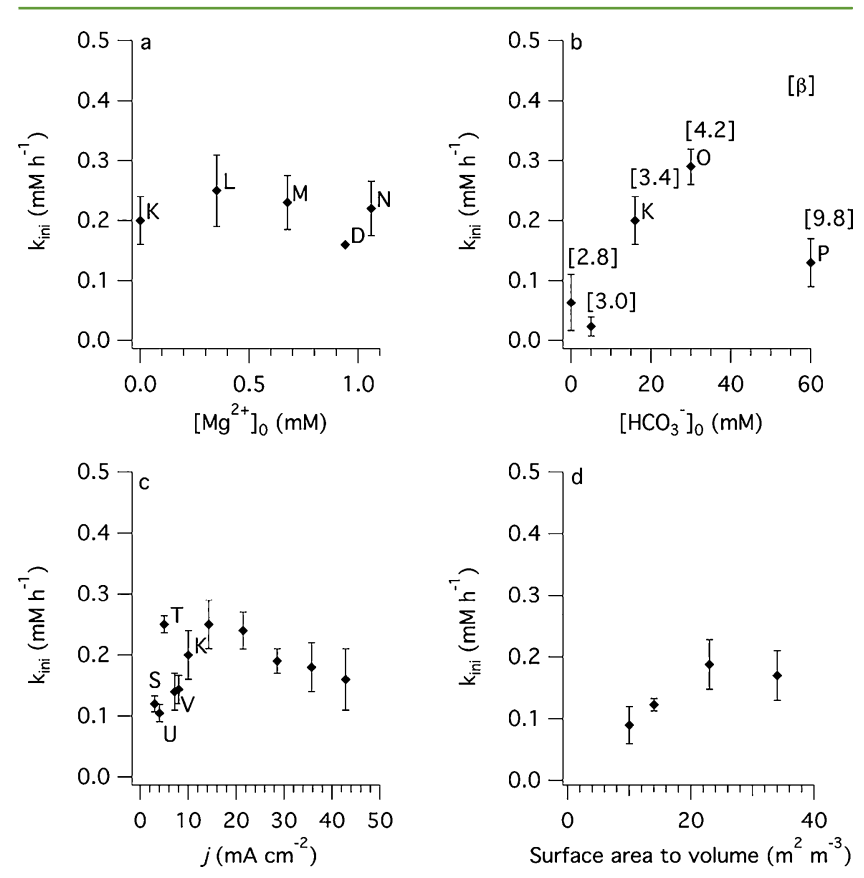

Figure 7. Initial phosphate removal rate following galvanostatic electrolysis ( $4 \mathrm{~h} ; 10 \mathrm{~mA} \mathrm{~cm}^{-2}$ unless noted otherwise) as a function of (a) $\left[\mathrm{Mg}^{2+}\right]_{0}$; (b) $\left[\mathrm{HCO}_{3}^{-}\right]_{0}$; (c) electrolysis current density, j; and (d) electrode surface area to volume ratio. Error bars represent \pm standard deviation of three replicates. Experiments are referenced by letter and are described in Table S1. (b) buffering capacity $\beta\left(\right.$ meq $\left.\mathrm{L}^{-1} \mathrm{pH}^{-1}\right)$ is noted in brackets. 

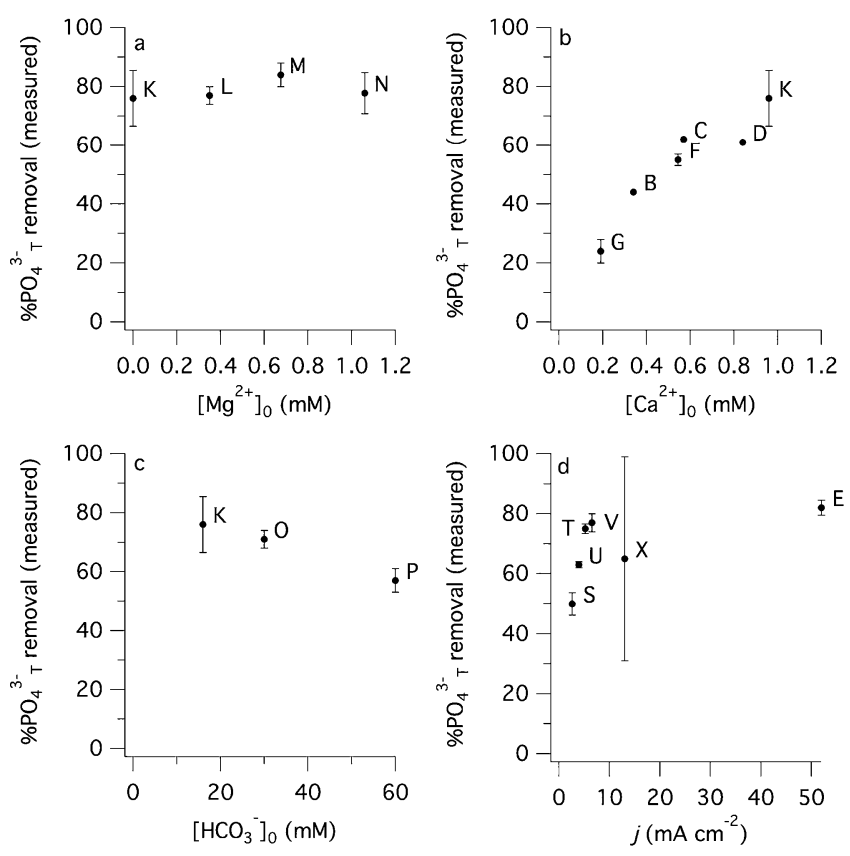

Figure 8. Measured percent total phosphate removal following galvanostatic electrolysis $\left(4 \mathrm{~h} ; 10 \mathrm{~mA} \mathrm{~cm}{ }^{-2}\right.$ unless noted otherwise) as a function of (a) $\left[\mathrm{Mg}^{2+}\right]_{0}$; (b) $\left[\mathrm{Ca}^{2+}\right]_{0} ;$ (c) $\left[\mathrm{HCO}_{3}^{-}\right]_{0}$; and (d) electrolysis current density, $j$. Error bars represent \pm standard deviation of three replicates. Experiments are referenced by letter and are described in Table S1 and Figure S2.

with $1 \mathrm{mM} \mathrm{Mg}^{2+}$ to $\mathrm{F}, \mathrm{K}$, and $\mathrm{G}$ with $0 \mathrm{mM} \mathrm{Mg}^{2+}$ ). This may have been due to magnesium compensating for the deficiency in calcium. Magnesium is therefore not expected to hamper electrochemical phosphate removal at concentrations typical of toilet wastewater.

Effect of Bicarbonate on Phosphate Removal. Toilet wastewater stored in onsite treatment systems will produce bicarbonate due to hydrolysis of urea. ${ }^{49}$ Previous studies have reported reductions in homogeneous hydroxyapatite precipitation by more than $40 \%$ with addition of carbonate, due to increased solubility of carbonate-substituted hydroxyapatite. ${ }^{35,43,50}$ Bicarbonate may also reduce hydroxyapatite precipitation by increasing the buffering capacity $(\beta)$ of wastewater, inhibiting the increased cathodic $\mathrm{pH}$ that initiates precipitation. $^{51}$

As expected, phosphate removal was significantly reduced at high bicarbonate concentrations (i.e., $57 \pm 3 \%$ removal at 60 $\mathrm{mM} \mathrm{HCO}_{3}{ }^{-}$vs $\sim 70-75 \%$ removal at 16 to $30 \mathrm{mM} \mathrm{HCO}_{3}{ }^{-}$; Figure $8 \mathrm{c}$ ). Phosphate removal rates were also slightly reduced at $60 \mathrm{mM}$ bicarbonate (Figure $7 \mathrm{~b}$ ), although the difference was not significant (i.e., $0.13 \pm 0.04 \mathrm{mM} \mathrm{h}^{-1}$ at $60 \mathrm{mM} \mathrm{HCO}_{3}^{-}$vs $0.17-0.23 \mathrm{mM} \mathrm{h}^{-1}$ at $16-30 \mathrm{mM} \mathrm{HCO}_{3}^{-}$).

The effect of bicarbonate on phosphate removal was attributed to the increased solubility of carbonate-substituted hydroxyapatite, as bicarbonate is not predicted to increase buffering capacities sufficiently to affect phosphate removal at concentrations typical of toilet wastewater (i.e., $<100 \mathrm{mM}$ ). This assertion was supported by experiments in buffered synthetic wastewater with buffering capacities ranging from 3.6 to 25 mequiv $\mathrm{L}^{-1} \mathrm{pH}^{-1}(0-100 \mathrm{mM}$ borate $)$ at $\mathrm{pH} 8.3$. Buffering capacity $(\beta)$ was calculated by eq 5 :

$$
\beta=\sum_{\mathrm{i}} \frac{2.3 C_{i} K_{\mathrm{a}, i}\left[\mathrm{H}^{+}\right]}{\left(K_{\mathrm{a}, \mathrm{i}}+\left[\mathrm{H}^{+}\right]\right)^{2}}
$$

where $C_{i}$ and $K_{\mathrm{a}, i}$ are the concentration and acid dissociation constant of species $i$, respectively. Phosphate removal rates were only affected at buffering capacities of 14.2 mequiv $\mathrm{L}^{-1}$ $\mathrm{pH}^{-1}$ and above (50-100 $\mathrm{mM}$ borate; Figure S8). This was considerably higher than the buffering capacity of toilet wastewater at elevated bicarbonate concentrations (i.e., 5.6 mequiv $\mathrm{L}^{-1} \mathrm{pH}^{-1}$ at $60 \mathrm{mM} \mathrm{HCO}_{3}^{-} ; 7.4$ mequiv $\mathrm{L}^{-1} \mathrm{pH}^{-1}$ at $100 \mathrm{mM} \mathrm{HCO}_{3}^{-}$).

Effect of Current Density and Treatment Volume on Phosphate Removal. Increasing current density increases the rate of proton consumption at the cathode and, depending on the buffering capacity of the wastewater, can therefore increase the $\mathrm{pH}$ near the cathode, ${ }^{52}$ favoring hydroxyapatite precipitation.

As expected, initial phosphate removal rates (Figure 7c) and total phosphate removal (Figure $8 \mathrm{~d}$ ) increased from about $50 \%$ with an initial rate of about $0.1 \mathrm{mM} \mathrm{h}^{-1}$ at $2.6 \mathrm{~mA} \mathrm{~cm}^{-2}$ to greater than $75 \%$ with an initial rate of about $0.25 \mathrm{mM} \mathrm{h}^{-1}$ at 15 $\mathrm{mA} \mathrm{cm}{ }^{-2}$. Increases in surface area to synthetic wastewater volume ratio augmented the rate of phosphate removal (Figure $7 \mathrm{~d}$ ) but did not change significantly affect the amount of energy required per volume of wastewater (Figure S9, inset). For example, achieving $60 \%$ total phosphate removal required $30 \pm$ $5 \mathrm{kWh} \mathrm{m}^{-3}$ at all surface area to volume ratios tested, but occurred after about $7 \mathrm{~h}$ at $10 \mathrm{~m}^{2} \mathrm{~m}^{-3}$ and after only $2 \mathrm{~h}$ at 34 $\mathrm{m}^{2} \mathrm{~m}^{-3}$.

Design and Operation Considerations. During pilotscale experiments, electrochemical phosphate precipitation resulted in scaling on the cathode (Figure S1), which subsequently fell into solution as approximately $1 \mathrm{~cm}^{2}$ flakes. Although cathodic scaling did not adversely affect wastewater treatment over short-term tests (i.e., less than 200 treatment cycles), complete cathode coverage by the precipitate during long-term operation may be problematic. Sustainable phosphate removal therefore requires electrode maintenance to remove and collect deposited precipitate. Although electrodes can be cleaned manually, this process could also be accomplished automatically by periodically polarizing the hydroxyapatite-coated stainless steel plates anodically. In addition, post-treatment hydroxyapatite collection could be automated, for example by incorporating a funnel into the bottom of electrochemical reactors, providing a phosphorusrich precipitate that could be used as a fertilizer at minimum cost. $^{53}$

In addition to human waste in onsite toilet treatment systems, electrochemical treatment would likely be effective for other phosphate-rich waste streams including agricultural wastes, such as animal husbandry wastewater. Dairy manure waste has a similar composition to toilet wastewater, ${ }^{35}$ and in addition to phosphate removal, electrochemical treatment provides disinfection, nitrogen removal, and chemical oxygen demand reduction with no additional electrochemical energy costs.

\section{ASSOCIATED CONTENT}

\section{Supporting Information}

The Supporting Information is available free of charge on the ACS Publications website at DOI: 10.1021/acssuschemeng.7b03155. 
Additional Figures S1-S9 and Table S1 as discussed in the text. (PDF)

\section{AUTHOR INFORMATION}

\section{Corresponding Author}

*E-mail: mrh@caltech.edu.

\section{ORCID $\odot$}

Clément A. Cid: 0000-0002-7293-035X

Justin T. Jasper: 0000-0002-2461-5283

\section{Author Contributions}

${ }^{\dagger}$ C.A.C. and J.T.J. contributed equally to this work.

\section{Notes}

The authors declare no competing financial interest.

\section{ACKNOWLEDGMENTS}

This research was supported by the Bill and Melinda Gates Foundation (Grants OPP 1069500 and OPP 1111246) and a Resnick Sustainability Postdoctoral Fellowship to J.T.J.

\section{REFERENCES}

(1) Correll, D. L. The role of phosphorus in the eutrophication of receiving waters: a review. J. Environ. Qual. 1998, 27 (2), 261-266.

(2) Conley, D. J.; Paerl, H. W.; Howarth, R. W.; Boesch, D. F.; Seitzinger, S. P.; Havens, K. E.; Lancelot, C.; Likens, G. E. Controlling eutrophication: nitrogen and phosphorus. Science 2009, 323 (5917), 1014-1015.

(3) World Bank Global Economic Monitor Commodities, http:// databank.worldbank.org/; accessed 8/29/2017).

(4) Karunanithi, R.; Szogi, A.; Bolan, N. S.; Naidu, R.; Ok, Y. S.; Krishnamurthy, S.; Seshadri, B. Environmental Materials and Waste; Academic Press: New York, 2016; pp 687-705, Chapter 27: Phosphorus Recovery From Wastes.

(5) Mihelcic, J. R.; Fry, L. M.; Shaw, R. Global potential of phosphorus recovery from human urine and feces. Chemosphere 2011, 84 (6), 832-839.

(6) Cordell, D.; Rosemarin, A.; Schröder, J. J.; Smit, A. L. Towards global phosphorus security: A systems framework for phosphorus recovery and reuse options. Chemosphere 2011, 84 (6), 747-758.

(7) Simons, A.; Solomon, D.; Chibssa, W.; Blalock, G.; Lehmann, J. Filling the phosphorus fertilizer gap in developing countries. Nat. Geosci. 2014, 7 (1), 3-3.

(8) de-Bashan, L. E.; Bashan, Y. Recent advances in removing phosphorus from wastewater and its future use as fertilizer (19972003). Water Res. 2004, 38 (19), 4222-4246.

(9) Oehmen, A.; Lemos, P. C.; Carvalho, G.; Yuan, Z.; Keller, J.; Blackall, L. L.; Reis, M. A. Advances in enhanced biological phosphorus removal: from micro to macro scale. Water Res. 2007, 41 (11), 2271-2300.

(10) Fumasoli, A.; Etter, B.; Sterkele, B.; Morgenroth, E.; Udert, K. M. Operating a pilot-scale nitrification/distillation plant for complete nutrient recovery from urine. Water Sci. Technol. 2016, 73 (1), 215222.

(11) Morse, G. K.; Brett, S. W.; Guy, J. A.; Lester, J. N. Review: Phosphorus removal and recovery technologies. Sci. Total Environ. 1998, 212 (1), 69-81.

(12) Hug, A.; Udert, K. M. Struvite precipitation from urine with electrochemical magnesium dosage. Water Res. 2013, 47 (1), 289299.

(13) Lacasa, E.; Cañizares, P.; Sáez, C.; Fernández, F. J.; Rodrigo, M. A. Electrochemical phosphates removal using iron and aluminium electrodes. Chem. Eng. J. 2011, 172 (1), 137-143.

(14) Tran, N.; Drogui, P.; Blais, J.-F.; Mercier, G. Phosphorus removal from spiked municipal wastewater using either electrochemical coagulation or chemical coagulation as tertiary treatment. Sep. Purif. Technol. 2012, 95, 16-25.
(15) Kruk, D. J.; Elektorowicz, M.; Oleszkiewicz, J. A. Struvite precipitation and phosphorus removal using magnesium sacrificial anode. Chemosphere 2014, 101, 28-33.

(16) Gorni-Pinkesfeld, O.; Shemer, H.; Hasson, D.; Semiat, R. Electrochemical Removal of Phosphate Ions from Treated Wastewater. Ind. Eng. Chem. Res. 2013, 52 (38), 13795-13800.

(17) Wang, C. C.; Hao, X. D.; Guo, G. S.; van Loosdrecht, M. C. M. Formation of pure struvite at neutral $\mathrm{pH}$ by electrochemical deposition. Chem. Eng. J. 2010, 159 (1-3), 280-283.

(18) Comninellis, C.; Chen, G. Electrochemistry for the Environment; Springer-Verlag: New York, 2010; Vol. 2015.

(19) Hoffmann, M. R.; Aryanfar, A.; Cho, K.; Cid, C. A.; Kwon, D.; $\mathrm{Qu}, \mathrm{Y}$. Self-contained, pv-powered domestic toilet and wastewater treatment system. Google Patents: 2013.

(20) Cho, K.; Hoffmann, M. R. Urea Degradation by Electrochemically Generated Reactive Chlorine Species: Products and Reaction Pathways. Environ. Sci. Technol. 2014, 48 (19), 11504-11511.

(21) Cho, K.; Hoffmann, M. R. BixTi1-xOz Functionalized Heterojunction Anode with an Enhanced Reactive Chlorine Generation Efficiency in Dilute Aqueous Solutions. Chem. Mater. 2015, 27 (6), 2224-2233.

(22) Yang, Y.; Shin, J.; Jasper, J. T.; Hoffmann, M. R. Multilayer Heterojunction Anodes for Saline Wastewater Treatment: Design Strategies and Reactive Species Generation Mechanisms. Environ. Sci. Technol. 2016, 50 (16), 8780-8787.

(23) Cho, K.; Qu, Y.; Kwon, D.; Zhang, H.; Cid, C. A.; Aryanfar, A.; Hoffmann, M. R. Effects of Anodic Potential and Chloride Ion on Overall Reactivity in Electrochemical Reactors Designed for SolarPowered Wastewater Treatment. Environ. Sci. Technol. 2014, 48 (4), 2377-2384.

(24) Huang, X.; Qu, Y.; Cid, C. A.; Finke, C.; Hoffmann, M. R.; Lim, K.; Jiang, S. C. Electrochemical disinfection of toilet wastewater using wastewater electrolysis cell. Water Res. 2016, 92, 164-172.

(25) Jasper, J. T.; Shafaat, O. S.; Hoffmann, M. R. Electrochemical Transformation of Trace Organic Contaminants in Latrine Wastewater. Environ. Sci. Technol. 2016, 50 (18), 10198-208.

(26) Weres, O.; O'Donnell, H. E. Multilayer oxide coated valve metal electrode for water purification. U.S. Patent 6,589,405, 2003.

(27) Weres, O. Electrode with surface comprising oxides of titanium and bismuth and water purification process using this electrode. U.S. Patent 7,494,583, 2009.

(28) Jasper, J. T.; Yang, Y.; Hoffmann, M. R. Toxic Byproduct Formation during Electrochemical Treatment of Latrine Wastewater. Environ. Sci. Technol. 2017, 51 (12), 7111-7119.

(29) Hoffmann, M. R.; Aryanfar, A.; Cho, K.; Cid, C. A.; Kwon, D.; $\mathrm{Qu}, \mathrm{Y}$. Self-contained, PV-powered domestic toilet and wastewater treatment system. 2013.

(30) Gustafsson, J. P. Visual MINTEQ ver. 3.1 (released 2014), 2014.

(31) McDowell, H.; Gregory, T. M.; Brown, W. E. Solubility of $\mathrm{Ca} 5(\mathrm{P} 04) 3 \mathrm{OH}$ in the System $\mathrm{Ca}(\mathrm{OH}) 2-\mathrm{H} 3 \mathrm{P} 04-\mathrm{H} 20$ at 5, 15, 25, and $37^{\circ}$ C. J. Res. Natl. Bur. Stand., Sect. A 1977, 81A (2-3), 273-281.

(32) American Public Health Association Standard Methods for the Examination of Water and Wastewater, 19th ed.; American Public Health Association, A.W.W.A., Water Environment Federation: Washington, DC, 1995.

(33) Loeppert, R. H.; Suarez, D. L. Carbonate and gypsum. In Methods of Soil Analysis, Part 3 Chemical Methods, 2 ed.; Sparks, D. L., Ed.; American Society of Agronomy: Madison, WI, 1996.

(34) White, G. C. White's handbook of chlorination and alternative disinfectants; John Wiley \& Sons: Hoboken, NJ, 2010.

(35) Cao, X.; Harris, W. Carbonate and magnesium interactive effect on calcium phosphate precipitation. Environ. Sci. Technol. 2008, 42 (2), $436-442$.

(36) Amjad, Z.; Koutsoukos, P. G.; Nancollas, G. H. The crystallization of hydroxyapatite and fluorapatite in the presence of magnesium ions. J. Colloid Interface Sci. 1984, 101 (1), 250-256.

(37) Ito, A.; Maekawa, K.; Tsutsumi, S.; Ikazaki, F.; Tateishi, T. Solubility product of $\mathrm{OH}$-carbonated hydroxyapatite. J. Biomed. Mater. Res. 1997, 36 (4), 522-528. 
(38) Golubev, S. V.; Pokrovsky, O. S.; Savenko, V. S. Unseeded precipitation of calcium and magnesium phosphates from modified seawater solutions. J. Cryst. Growth 1999, 205 (3), 354-360.

(39) Gibson, I. R.; Best, S. M.; Bonfield, W. Chemical characterization of silicon-substituted hydroxyapatite. J. Biomed. Mater. Res. 1999, 44 (4), 422-428.

(40) Sprio, S.; Tampieri, A.; Landi, E.; Sandri, M.; Martorana, S.; Celotti, G.; Logroscino, G. Physico-chemical properties and solubility behaviour of multi-substituted hydroxyapatite powders containing silicon. Mater. Sci. Eng., C 2008, 28 (1), 179-187.

(41) Dai, H.; Lu, X.; Peng, Y.; Yang, Z.; Zhsssu, H. Effects of supersaturation control strategies on hydroxyapatite (HAP) crystallization for phosphorus recovery from wastewater. Environ. Sci. Pollut. Res. 2017, 24 (6), 5791-5799.

(42) Spanos, N.; Koutsoukos, P. G. Kinetics of precipitation of calcium carbonate in alkaline $\mathrm{pH}$ at constant supersaturation. Spontaneous and seeded growth. J. Phys. Chem. B 1998, 102 (34), 6679-6684.

(43) Cao, X.; Harris, W. G.; Josan, M. S.; Nair, V. D. Inhibition of calcium phosphate precipitation under environmentally-relevant conditions. Sci. Total Environ. 2007, 383 (1-3), 205-215.

(44) Putnam, D. F. Composition and concentrative properties of human urine; NASA Contractor Report CR-1802, 1971.

(45) Inskeep, W. P.; Silvertooth, J. C. Kinetics of hydroxyapatite precipitation at $\mathrm{pH} 7.4$ to 8.4. Geochim. Cosmochim. Acta 1988, 52 (7), $1883-1893$.

(46) Okazaki, M.; Takahashi, J.; Kimura, H. Unstable behavior of magnesium-containing hydroxyapatites. Caries Res. 1986, 20 (4), 324331.

(47) Fuierer, T. A.; LoRe, M.; Puckett, S. A.; Nancollas, G. H. A Mineralization Adsorption and Mobility Study of Hydroxyapatite Surfaces in the Presence of Zinc and Magnesium Ions. Langmuir 1994, 10 (12), 4721-4725.

(48) TenHuisen, K. S.; Brown, P. W. Effects of magnesium on the formation of calcium-deficient hydroxyapatite from CaHPO4. $2 \mathrm{H} 2 \mathrm{O}$ and Ca4 (PO4) 2O. J. Biomed. Mater. Res. 1997, 36 (3), 306-314.

(49) Udert, K. M.; Larsen, T. A.; Gujer, W. Fate of major compounds in source-separated urine. Water Sci. Technol. 2006, 54 (11-12), 413420.

(50) Kapolos, J.; Koutsoukos, P. G. Formation of Calcium Phosphates in Aqueous Solutions in the Presence of Carbonate Ions. Langmuir 1999, 15 (19), 6557-6562.

(51) Shirkhanzadeh, M. Direct formation of nanophase hydroxyapatite on cathodically polarized electrodes. J. Mater. Sci.: Mater. Med. 1998, 9 (2), 67-72.

(52) Dahms, H.; Croll, I. M. The Anomalous Codeposition of IronNickel Alloys. J. Electrochem. Soc. 1965, 112 (8), 771-775.

(53) Moriyama, K.; Kojima, T.; Minawa, Y.; Matsumoto, S.; Nakamachi, K. Development of Artificial Seed Crystal for Crystallization of Calcium Phosphate. Environ. Technol. 2001, 22 (11), 12451252. 